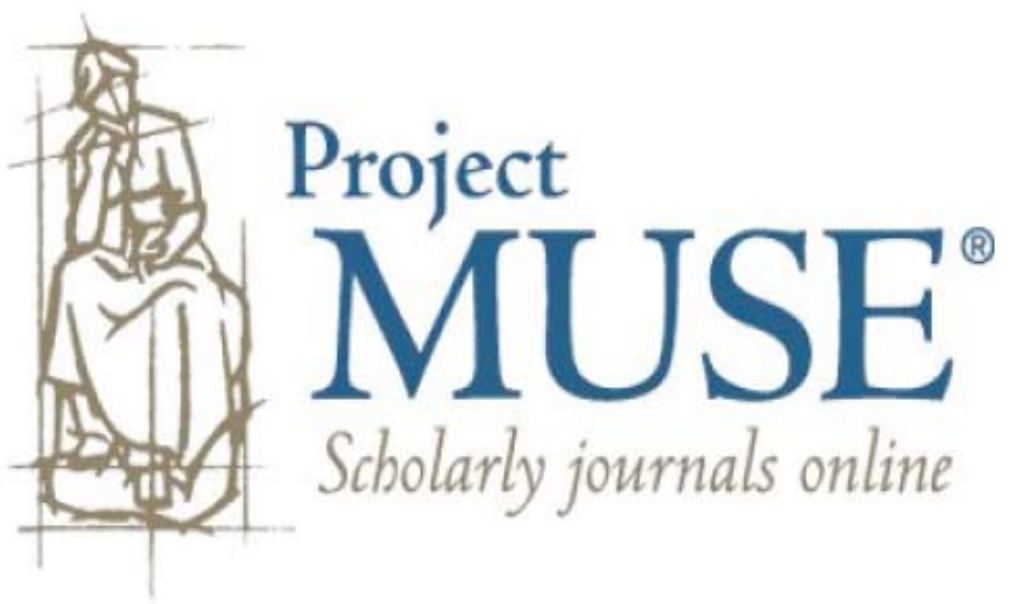




\title{
REPORTING FOR DUTY
}

\author{
$\cong$ \\ The Bohemian Brigade, the Civil War, and the Social \\ Construction of the Reporter
}

Andie Tucher

Just a few years before the Civil War, in a beer cellar just a stone's throw from the assembly hall where the polka had been danced in New York City for the first time, began a turning point in the social construction of the reporter.

Historians interested in the development of journalism as a profession generally agree on two other landmarks that bracket that one. The reporter himself, they agree, was born in the 1830 (the reporter berself generally came later) as a necessary agent of the new urban penny press, which was redefining the idea of "news" to mean not the customary commercial or partisan intelligence but rather gathered information about everyday life that was timely, accurate, independent, enterprising, and commercially valuable. Most also agree that the reporter began to take on many of the generally accepted sociological characteristics of a professional in the late nineteenth and early twentieth centuries, when journalists joined the members of other emerging vocations such as law, medicine, and teaching in the widespread effort to identify, organize, and control the distinctive bodies of knowledge, codes of behavior, and modes of inquiry that set them apart from ordinary people. For journalism, and for journalists, objectivity became the ideal that not merely defined the profession but actually legitimated it-a somewhat desperate measure, as Michael Schudson has argued in his influential study, or at least a defensive one, taken in response to the increasingly clear 
understanding that overcoming subjectivity in presenting the news was not actually possible. ${ }^{1}$

While those two landmarks are generally accepted without dispute, the one I propose is somewhat more contentious. In fact, Schudson explicitly rejects the notion that the Civil War marked a "turning point" in American press history, arguing that "It did not 'turn' the direction of journalism; its impact was to intensify the direction in which journalism had been turning since the I 830 os." ${ }^{2}$ Yet while I agree that the tactics and techniques used by reporters for gathering the news did not materially change during the war era, I contend that the journalists' sense of themselves and their work did. For the first time, people engaged in everyday newsgathering were making an effort to craft their public image, to present to the world their own picture of who reporters were, what reporters did, and why the public should care. For the first time, some journalists-a small group of them, to be sure, though among them were some of the most influential practitioners on some of the largest-circulation papers of the day-were not just doing their job of reporting but were also writing about their job of reporting, making explicit claims about their rights and responsibilities as narrators of the nation's stories. Journalists were, in other words, beginning to think of and present themselves as a class apart—as professionals.

In books intended for a mass audience they recorded what they thought about the work they did. They pictured themselves as a special kind of person, doing a special job in a particular way that others could not manage, with privileges and obligations that others did not share, and that provided a public service crucial to the well-being of the citizenry. At the same time, newspaper writing, at least for the flagship metropolitan press, was taking clear shape as something different from other kinds of literature, the newspaper as the exclusive and appropriate home for this kind of writing, and the journalist as the kind of writer most particularly suited for this work. In fact, journalists were seeking a double distinction, differentiating themselves not just from ordinary people but also from the many other kinds of authors-novelists, playwrights, poets-who were also struggling to define themselves as skilled professionals. Like those literary writers, journalists were concerned with the most basic components of professional recognition: Would they be adequately paid? Would they be respected as possessors of a talent not everyone had? But the particular kind of writing they did-the construction, every day, through the use of special interpretive techniques and while abiding by certain standards, of a picture of the world that readers would endorse as factually accurate and accept as true-to-life-required building a rather complex and collaborative relationship with their public in which not just questions of recognition and pay but also such classic professional issues as social authority, credibility, 
duty, and trust loomed large. And if in the twentieth century the professional journalist would learn to submerge his or her self in the impersonal and unemotional guise of the objective witness, it was here, during and after the Civil War, that journalists began to construct the self that would later have to be submerged.

It is not incidental that one recurring and highly symbolic motif in both the self-construction and the later submersion was beer. Even more significant is that some of the most alarmist members of what became in effect a teetotaler party were journalists themselves, who deployed (and sometimes exploited) that motif with all the anxiety and shrewdness of a temperance-meeting orator. Tracing the buoyant rise and swift fall of the particular kind of reporter known as the Bohemian offers a look into the often bumpy development of the profession, and the perception, of journalism.

The beer cellar where it all began was Pfaff's, a raffish place established in I856 at the corner-or rather under the corner-of Bleecker Street and Broadway in Manhattan, which was then part of the entertainment district. It soon became the haunt of a circle of young writers and other artists who were consciously trying to emulate the jauntily threadbare and proudly unconventional lives of the Parisian artists portrayed by Henri Murger in his recent novel Scènes de la vie bohème, which gave the image of the "Bohemian" to the world and would later inspire Puccini's opera $\mathrm{La}$ bohème.

The title of King of New York's Bohemia belonged by acclamation to Henry Clapp, a reformer and Fourierist who had actually lived for some time in Paris. In I 858 he founded a weekly journal of literature, criticism, and the arts called the Saturday Press, whose devotion to the continental style he proclaimed as early as the third issue with the initial installment of a six-part serial called "A New Portrait of Paris Painted from Life" and written by himself. The paper was, recalled its managing editor long afterward, "piquant, satirical, pugnacious, often fraught with quips and jibes relative to unworthy reputations of the hour, and, likewise, it must be admitted, sometimes relative to writers who merited more considerate treatment." ${ }^{3}$

Clapp championed Walt Whitman, introduced Mark Twain to eastern readers, and valued the feuilleton above all other kinds of work and the bon mot above all other kinds of word. Ambitious young writers throughout the country were soon lusting for publication in his periodical. Clapp was also, in classic Bohemian style, chronically penniless, hiding from his creditors and unable to pay his contributors. Forced to suspend the struggling paper in December I 860 after just two years, Clapp revived it shortly after the 
end of the war, announcing that he had stopped it "for want of money" and would now "revive it ... for the same reason." 4 It didn't last long that time around either.

Most of those cellar Bohemians are forgotten today. While the Bohemian sensibility demanded that they pursue their art for love rather than money, in practical terms the antebellum American literary scene didn't really offer them much choice. The profession of authorship was not yet capacious enough to offer more than a few the opportunity to earn a decent living by the pen alone, and even the best-known and best-selling authors generally had either an independent income or a day job. ${ }^{5}$

The aspiring writer's problem wasn't a lack of outlets. Throughout the I $830 \mathrm{os}$, I840s, and I85os, plenty of magazines, reviews, and journals offered a home for essays, poetry, stories, correspondence, criticism, and humorous sketches-but that home could be spare and comfortless indeed. Overpriced in comparison to the English authors whose pirated works could be published much more cheaply, as vulnerable as any luxury good to the vagaries of the tumultuous economic climate, and undermined by the fading but tenacious tradition of the unpaid "gentleman amateur" writer, authors simply weren't paid well, if they were paid at all. A few editors, notably George Graham of Graham's Magazine and Sarah Hale of Godey's Lady's $B o o k$, were bucking tradition by accepting only original contributions and paying their authors decently for them; Edgar Allen Poe's work for Hale, for instance, essentially kept him afloat in I 845 and I 846 . And in the attention paid by diligent editors like Hale to the quality of the work they published can be glimpsed the beginnings of the idea that authorship required a particular kind of talent, that practice and guidance could improve that talent, and that authors deserved pay and respect commensurate with their talent-in short, the idea of professionalism as it applied to the belles lettres. ${ }^{6}$

But while the idea of a profit-making author was no longer preposterous in a few quarters, the reality was rare. Even the liberal Hale rarely paid beginning writers, and in I 852 one of her own female contributors warned would-be sister authors that there were only "perhaps ten or twelve ladies in our own country who have adopted literature as a profession," only six of whom, with incessant industry, "realize a comfortable, barely comfortable, income." Nor were the odds any better for the male sex, at least according to Horace Greeley in his reply to an aspiring poet who, after getting published in the story paper Brother Jonathan, wrote seeking the editor's advice about coming to New York to make his fortune as a writer. "Alas! my friend," Greeley wrote young H. Hubbard of Chenango County in upstate New York, "you know not what it is that it is [sic] wanted of men who live by literary labor here.... There are a thousand at least in this city who can write very good prose or verse ... while there are not fifty who can earn their 
bread by it.... I don't believe there is a loaf of bread to be got here by mere good writing once a year." 7

If the profession of authorship was minuscule in the antebellum period, its subset, the profession of journalism, had no coherent shape at all, sheltering under its ample umbrella an enormous variety of practitioners united by no other common bond than their association with a recurrent and ephemeral form of print. In an era when political parties depended heavily on the newspapers they themselves established and funded to rally their supporters and advance their political goals, many a person who rejoiced in the title "editor" functioned less as a man of letters than a political activist-"his party's principal spokesman, supplier of ideology, and enforcer of discipline ... the party's face and voice." 8

The "reporter," meanwhile, was virtually unknown outside of the biggest cities. A handful of Washington papers maintained staffs of accomplished stenographers to take notes of proceedings in the halls of Congress, and the urban commercial papers used a variety of tactics, technologies, and energetic assistants to rush the very latest financial intelligence to the merchants and bankers who relied on them. Most dependent on reporters-in fact rooting their very identities in their need for reporters-were the big-city penny papers, chief among them the Sun, the Tribune, the Herald, and the Times of New York, all of them founded between I8 33 and I 85 I. In a break with tradition, the penny editors fashioned their papers for the general urban public rather than the elite merchants and political men. Freeing themselves from both the trammels and the security of partisan funding, they relied for their profits on sales and advertisements alone, and gambled that they could attract a mass audience among the middle-class and working-class citydwellers who had never before found newspapers particularly important to their lives or well-being. Boasting that they printed "all the news of the day," the penny editors focused on the kind of local and human-interest stories that had never before been considered worthy of enshrinement in a newspaper and began hiring stables of active young reporters whose job it was to go out, find those stories, and write them up. Indecent, sensational, or intrusive they may sometimes have been, at least in the eyes of some disapproving observers, but they were also commercially valuable, as tens of thousands of readers swiftly learned to enjoy the breezy up-to-the-minute narratives about everything from the prize fight to the Fifth Avenue costume ball to the mysterious murder in an elegant house of prostitution. And as the idea caught on and spread to other big cities, the more successful papers began to send their reporters farther and farther afield and to compete more and more vigorously to get the news first. ${ }^{9}$

But not even the most breathless penny papers restricted their columns to the news their reporters tracked down and brought in; they also opened their 
pages wide to poetry, stories, and other belles lettres, which they saw not as mere entertainment but rather as engines of refinement and enlightenment that were just as deserving of column inches as the latest happenings in the police court, the circus, and the streets. In so doing, they were embracing yet another style of newspaper journalism, one most characteristic of the country and local press, which itself was following in the tradition of the magazine. The hundreds of newspapers issued in towns, villages, and hamlets across the country- 1,902 of the 2,302 titles published in 1850 were weeklies, the classic format for the small-circulation paper-tended to be precariously shoestring, highly collaborative, generally hospitable, and notably miscellaneous enterprises. ${ }^{10}$ Except for the editorial columns, which generally bore the strong and often partisan imprint of the editor himself, the typical local newspaper sang with a haphazard multitude of voices, genres, and styles—and because it usually came out weekly, its song was much more frequent and its need for content much more relentless than the typical monthly magazine's.

For these papers, news was not stuff that was gathered with deliberation by people who were paid for that purpose; rather it was stuff that came in, information and entertainment and whatever else turned up that could fill those yawning column inches and appeal to the widest possible variety of readers' tastes. Messages from the president and political fare from party functionaries adjoined international affairs and market intelligence, which lay adjacent to the local laws, which appeared next to paragraphs about tragic accidents or odd natural phenomena copied from the exchange papers, which bumped up against jokes, short stories, farming tips, letters from travelers, historical essays, biographical sketches of great men, homilies, tall tales, comic dialogues, and "a few lines" that had been slipped under the editor's door by a blushing versifier. ${ }^{11}$

In this universe the "reporter" was completely unnecessary and generally unknown; anyone, it seemed, could wend his or her way into the newspaper. Sometimes it took no skill more special than being in the right neighborhood. In the spring of I836 readers as far away as Vincennes, Indiana, found themselves indebted to the "politeness of a gentleman at San Augustine" in Texas for informing them via a daisy-chain of exchange papers of the disaster at the Alamo. Nor was audacity particularly necessary. Even an aspiring young poet hiding behind the appropriate alias "Freshman" could gain an audience with the local editor, which is how Franc Wilkie, who would go on to journalistic fame in New York and Chicago, got his start on the Schenectady Evening Star. ${ }^{12}$

In I93 I, Constance Rourke, pondering her discovery that most American comic writing, especially in the antebellum period, took the form of the short, fragmentary sketch rather than the full-length tome, argued in her 
influential American Humor that the short format was the embodiment of some massive imperfection in American culture, some embarrassing immaturity, some incapacity to fully articulate an organic native tradition that would merit the weighty Old-World respectability of the novel..$^{13}$ Perhaps. But a case could also be made that Seba Smith, Augustus Baldwin Longstreet, George Washington Harris, and other antebellum humorists wrote short sketches not because they couldn't think of anything longer but because they couldn't readily publish anything longer.

The enormous financial risks and expenses faced by the infant American book-publishing industry tended to seal its transoms nearly airtight against the unproven aspirant, especially one offering something as frivolous as a humorous piece. Important literary journals like the Knickerbocker and the Southern Literary Messenger oozed out just once a month. But even an unknown author with neither resources nor leisure could cherish a reasonable hope of breaking into print in the ubiquitous, frequent, cheap, and hungry medium of the local or specialized newspaper. Many of the most successful humorous books of the period, among them Smith's Major Downing Papers, Longstreet's Georgia Scenes, Mortimer Thomson's Doesticks: What He Says, George Derby's Phoenixiana, Henry Wheeler Shaw's Josh Billings, Hiz Sayings, and Harris's Sut Lovingood Yarns, had been published between covers only after the authors had proved their popularity, and their profitability, with those "fragmentary sketches" that precisely conformed to the columns of a newspaper. ${ }^{14}$

So it wasn't their insouciance about money that made the Bohemians at Pfaff's unique. Nor was it their very public devotion to arts and letters; America had had literary circles before, notable among them the crowd around Lewis Gaylord Clark's sophisticated Knickerbocker magazine. It wasn't even their unconventionality, which, though strenuous, did seem to observe some limits. By I860, when the tremulously young William Dean Howells made a pilgrimage to Pfaff's, its habitués had become so notorious that even some of Howells's neighbors in faraway Ohio knew their names. But when Howells finally descended into the cellar, the "brevet Bohemian" confessed himself disappointed by how "slowly" the alleged orgy was going and how pale were the traces of the "fearful debauch" reportedly survived by several of its members. (It was ridiculous for Howells to speak of debauchery at all, grumbled one ex-Bohemian years afterwards; since "revelry requires money," most of the writers at Pfaff's couldn't afford to be sots. $)^{15}$ This would not be the last time in the social construction of the journalist that beer loomed more important as a symbol than as an intoxicant.

What distinguished the Pfaff's group was the same trait that characterizes Bohemian bands in general: their shared conviction that they were different from everyone else around them. Taken together, their insouciance about 
money, their devotion to their art, their unconventionality, and of course their talent made them feel radically, irremediably not like other people even as they were like each other, a community apart, exclusive and close-knit and special, enjoying a "sentiment of fraternity," recalled one years later, "such as I have not since observed." 16 It was their membership in a small, gifted, unorthodox, and borborygmic band that gave them their deepest sense of themselves.

This agglutination of beery artistic types was more a community than a profession, but included in the community were some members in a position to carry its sense of exclusivity, fraternity, and dedication into the writing they did for more stable if still minuscule pay. Drawn into the group at Pfaff's were other bright young writers who contributed to Clapp's Saturday Press (or wished they did) at the same time that they wrote, as either staffers or stringers, for the big newspapers. The roster of those regulars varies from teller to teller, most of them reverently naming the same "leading lights" who have never been heard of since-Ned Wilkins, the Herald's drama critic, who died young, generally heads the list—but most of them wrote for either the Herald or the Tribune. In fact, the Tribune, widely read throughout the northern states and renowned for its literary heft and moral seriousness as well as for the eccentricities of its editor, Horace Greeley, quickly earned a reputation as a nest of Bohemianism-a reputation that Charles T. Congdon, a Tribune writer who did frequent Pfaff's during his youth, would later facetiously dismiss as a "vile slander." 17

Much more comfortable with both the label and the sensibility of the Bohemian-in fact, arguably the very personification of American Bohemianism - was Walt Whitman, the journalist-poet whose work on more than a dozen newspapers in Manhattan, Brooklyn, Long Island, and New Orleans had served as his apprenticeship in the techniques of exploring, observing, and describing the rude and rowdy bustle of city life that he would bring to flower in Leaves of Grass. In the late I850s, fresh from the less-than-satisfying publication of the first edition, Whitman found Henry Clapp's support invaluable and the cellar lair the most congenial spot in the city to continue his loafing. "You will have to know something about Henry Clapp," Whitman told a young acolyte years later, "if you want to know all about me." In the cellar Whitman's poetry was admired, his originality celebrated, his slightly disreputable persona appreciated, even his unorthodox wardrobe of open-necked shirts and rough workingmen's trousers relished; it was his radical difference from ordinary people, a difference that only they could fully appreciate, that led the Pfaff's crew to make of him almost "their cult," as Howells later recalled with some disapproval—for the cultists, not for Whitman. Still, even a Bohemian, or perhaps especially a Bohemian, could understood that bibulous hilarity 
could not hold the dark at bay forever, that art and literature and sharpedged banter had their limits, and during these years Whitman began a poem comparing "the vaults at Pfaff's, where the drinkers and laughers meet to eat and drink and carouse" beneath the hurrying feet of Broadway, to the vaults where the "dead in their graves are underfoot hidden." He never finished it, for reasons unknown. ${ }^{18}$

The outbreak of the Civil War sparked a general hunger for the latest news that made the newspaper an "imperious" necessity of daily life that, as Oliver Wendell Holmes put it, "will be had, and it will be read. To this all else must give place." ${ }^{19}$ It also gave the journalist the role of a lifetime. The reporters who flocked to cover the conflict included a large contingent from the pace-setting New York press, among them Albert Richardson of the Tribune, Thomas Knox of the Herald, Richard Colburn of the World, and the artists Alex Simplot of Harper's Weekly and Henri Lovie of Frank Leslie's Illustrated. There is no evidence specifically placing any of these men among the carousers in the beer cellar back home, but certainly any adventurous New York journalist, particularly a journalist from the Herald or the Tribune, would have at least known of Pfaff's-and when Richardson, Knox, and the others who gathered in late summer I86I at General Frémont's headquarters in Jefferson City, Missouri, chose to call themselves the "Bohemian Brigade," they were clearly and ostentatiously assuming the mantle of Pfaff's apostles. A select few Midwesterners were also permitted to join the Brigade, among them the honorary New Yorker Junius H. Browne, a Cincinnati Gazette man who had just been hired by the Tribune and who would become the most Bohemian brigadier of all. Nor was the Bohemians' self-label some secret password for themselves alone. As it swiftly earned the validation of general, and occasionally satiric, use, other correspondents on both sides of the conflict began to associate themselves explicitly, if perhaps wishfully, with the panache of the New York journalists, and "Bohemian" or derivatives thereof became such conventional pen names in papers as remote from the Bleecker Street cellar as Alabama's Mobile Register that the term began to sound almost like a synonym for "war correspondent." 20

Within months of the war's end, three of the original Bohemians had rushed into print with thick memoirs of their wartime experiences: Junius Browne with Four Years in Secessia: Adventures Within and Beyond the Union Lines; Thomas Knox with Camp-Fire and Cotton-Field: Southern Adventure in Time of War, Life With the Union Armies, and Residence on a Louisiana Plantation; and Albert Richardson with the dramatically titled The Secret Service, The Field, The Dungeon, and the Escape. Together these rank among the first actual reporters' autobiographies in America, 
the first memoirs whose focus was on the special work of newsgathering. All were popular, but Richardson's was a bona fide hit, selling I००,००० copies in six years. (He did, however, have a marketing advantage the others lacked: in 1869 Richardson was spectacularly murdered within the very sanctum of the Tribune by the legally divorced ex-husband of the woman he had asked to be his second wife.) More than twenty years later another honorary New Yorker, Franc Wilkie, who early in the war had been hired away from the Dubuque Herald by the New York Times, added yet another Bohemian memoir, Pen and Powder, to the hot-off-the-press narratives of his colleagues. ${ }^{21}$ Together the four books provide intriguing insights into how some of the best-known and most influential of the Civil War correspondents viewed the state of journalism and the work of the journalist-and, perhaps even more important, how they wished the public to see them.

The four works clearly reflect the varying personalities of their writers. Thomas Knox tended to be cooler and more serious than his fellow reporters, indulging in much less personal information (about his subjects as well as himself) and much more description of scenes and events, and although all of his colleagues included him in the standard list of Bohemians, he was the only one who did not himself invoke that label. In many places, in fact, his writing sounds close to the impersonal and observational style that has come to be accepted as "journalistic." His reserve is reflected in the paucity of surviving details about his life. He himself mentioned that in I 860 he had been reporting from the Rocky Mountain goldfields for a few eastern newspapers, but when war loomed, "wishing to take part in the drama about to be enacted," he traveled east to offer his services to the Herald at "any point between the Poles, wherever The Herald desired a correspondent." Franc Wilkie described him as a heavy, clumsy man "given to sarcastic utterances," but added that on a long horseback journey together he "came out strong as social, companionable, and genial," able to recite poetry from memory for hours without hesitation or error; Wilkie thought he'd been a teacher somewhere in New England before the war. ${ }^{22}$

Like Knox, the other three Bohemian authors were all under thirty when the war began, and all three left ample evidence of the same restless and romantic adventurousness that apparently drove Knox's flight from the schoolhouse to the goldfields and that seemed the major prerequisite for getting a job as a war correspondent. In $185 \mathrm{I}$, when he was just seventeen, Richardson left home and the family that had been farming in Massachusetts for seven generations, soon finding himself work he loved as a reporter in Cincinnati. Although he married young, at twenty-two, and fathered young, welcoming his first child less than five months after the wedding, his domestic duties didn't settle him down; scorning an offer to stay decorously at home as the editor of a Cincinnati paper, the young man 
went even farther west, reporting from Bleeding Kansas, riding with Kit Carson in New Mexico, and allegedly dreaming up the name for the new territory of Colorado. An encounter with Horace Greeley in a stagecoach eventually led him to a correspondent's billet with the New York Tribune, and throughout his book Richardson emphasized the importance of his work and his heavy responsibilities as a well-known correspondent of so influential a paper. He apparently carried that sense of importance over into some of his personal relationships. Although Knox counted Richardson a close friend, Wilkie confessed to disliking Richardson on sight, finding him "puritanical," a "pedant," a "prim, formal, precise" man who "assumed an air of superiority" because Wilkie was from the country. On top of that, as Wilkie wrote long after Richardson's death, the Tribune man had once tried to take advantage of Wilkie's momentary financial difficulties by buying from him a dispatch he had already promised to the Times - an act that the more experienced Richardson "knew much better than I then knew," seethed Wilkie, "to be a grave breach of faith." 23

Browne, on the other hand, Richardson's colleague on the Tribune, seemed more interested in the adventure than in the responsibilities of war correspondence; the attentions of the ladies grace his pages surprisingly often for a reminiscence of wartime, and his descriptions of battle, captivity, and death often bear a decidedly purple tinge. His colleagues described him as temperate in his habits, small and slender, something of a dandy, "cultured, scholarly, classical, and a poet," but also dramatically careless about his personal safety, at one point standing "all exposed" on a barge on the Mississippi that was coming under withering fire. He had graduated from St. Xavier College in Cincinnati but quit his father's bank after two years to become a journalist. ${ }^{24}$ Franc Wilkie's early experiences were the most dramatic of all. At twelve he ran away from his home in upstate New York, became a driver on the Erie Canal, and after being bilked of his wages made his way to New York, where he supported himself for two years as a paperboy and match-seller. After a brief stint back home on the family farm and some time at a small Schenectady college, he moved to Iowa, where he started his own short-lived paper and where the New York Times soon found and hired him. He lasted only about two years as a frontline correspondent, quitting after the Union victory at Vicksburg "satisfied" his "Western ambitions," but he put aside plans to write a book about military history when soon thereafter he received an unexpected offer of an editorial job on the Chicago Times. ${ }^{25}$ Though his memoir followed the others by nearly a quarter of a century, it was neither apologia nor revision, simply a fond account that sounded almost as timely as the others and only rarely acknowledged the intervention of the decades.

Evident in all of these memoirs is the conviction that journalists, and particularly the special crew that qualified as Bohemian journalists, were 
a different breed than ordinary mortals. They worked hard to shape and burnish their image as worthy representatives of the Pfaff's crowd, as rakish, raffish, irreverent adventurers whose eyes were always open, whose laughs were always last, and whose obligations to their art were always held as sacred. They "adopted the true Bohemian code of doing the best we could for our comfort, and of laughing away the multifarious annoyances that were inseparable from camp-life." They "discussed politics, art, society, and metaphysics; and would soon kindle into singing, reciting, 'sky-larking,' wrestling, flinging saddles, valises, and pillows"-which "everybody enjoyed ... except those who occupied adjoining rooms, and possessed a desire for sleep." They were equal to any occasion, writing their dispatches when necessary on horseback, on tree-stumps, on the chest of a sleeping comrade, under a hail of falling tree limbs cut down by artillery fire, at one end of a gambling table devoted to a noisy game of "Chuck-a-Luck." They strutted and swaggered and tossed off mots as bon as anything Henry Clapp ever printed; one Herald man, derided for never having read Shakespeare, was said to have replied that he feared the bard "would interfere with my style as a writer!" They prayed, but only "in our Bohemian way." Even the most fearsome generals knew their power, as General Sherman showed with his response to the (erroneous) news that three Bohemians had been killed: "That's good! We'll have dispatches now from hell before breakfast!" 26

But Bohemianism wasn't all metaphysics and pillow fights, and the serious and important public service the journalists performed also contributed heavily to their sense of their specialness. The fullest description of that service was offered by Browne in the opening chapter he devoted to detailing the responsibilities, sacrifices, character traits, accomplishments, and flaws of the war correspondent.

He is at his post to relate what he sees; to applaud valor and merit wherever found; to point out abuses and blunders that would not otherwise be reached, save through the endless duration of military investigations and courts-martial. His duty is to illustrate the situation so far as is prudent; to describe the movements, actions, and combinations of the forces; in a word, to photograph the life and spirit of the combatants for the benefit of the great Public, united to them by blood and sympathy, and who thrill and suffer with the gallant warriors, and mourn over and honor the heroic dead.

... The ill-starred Bohemian has a most delicate and difficult task to perform. He must do his duty, and yet offend no one. He must praise, but not censure. He must weave chaplets of roses without thorns for the brows of vanity, and applaud modest merit without wounding 
pompous conceit. Every thing is expected of him-impossibilities and virtues more than human. ${ }^{27}$

The reporter, in other words, was to be both human and machine, to provide not just a clear "photograph" of combat for his distant readers-this at a time when no daily newspaper had the technology to reproduce an actual photograph-but also correction, consolation, and applause for his fellow mortals.

This unique-even superhuman-role as first-hand observers, interpreters, and mediators of the war could earn the reporters no little deference and affection, particularly among the anxious families of the beloved "bold soldier boys," as Wilkie recalled, whose "representative and prophet" they were. The soldier boys themselves also appreciated the correspondents' unique understanding of the war they'd shared. In his I 888 memoir, Wilkie reprinted a letter from a veteran commending a nostalgic series based on his old war reporting. "You have so truthfully portrayed events," the ex-private from the 8th Wisconsin wrote the former correspondent from the New York Times, "and your pictures are so marked by fidelity that no doubt is left in the mind of an active participant that you have been there." 28

But that did not make reporters in any way soft or sentimental; their first-hand front-line experiences earned them a hard-edged wisdom that stay-at-homes lacked and imposed upon them an obligation to share that wisdom generously with those outside their special circle. Browne assured his readers that camp life "remov[ed] the romantic idea of War... War bristles with facts-is terribly real, repulsively practical ... a reign of horrors and a civilized monstrosity." Although he conceded, with the world-weary bravura so many of his successors share to this day, that war had its "fascinations, as drunkenness, licentiousness, murder, journalism, and the stage have theirs," it was nonetheless "high time War had ceased to be." Wilkie disabused his readers of the widely cherished notion that dying soldiers ever "arranged any of the beautiful sentiments so frequently published in some of the newspapers and in a certain class of books. 'Tell them that I have cheerfully given my life for my flag and my country," Wilkie wrote, "is an absurd invention." And Knox recalled almost nostalgically the "coldness" that crept over him the first time he faced battle, and lamented that the war "has made us familiar with horrors.... Our nerves have been hardened, our sensibilities blunted, our hearts steeled against suffering, in the terrible school through which we have passed."29

Although Civil War correspondents on the whole were notoriously overzealous in their pursuits of the exclusive and the scoop, the Bohemians at least seemed to hold certain obligations unimpeachable and to understand certain limits to permissible behavior-which, oddly enough, may be best 
illustrated by an episode that was distinctly shady. On March 20, I862, the Tribune published Junius Browne's masterful account, covering nearly a page and a half, of the Union victory at Pea Ridge in the wild and remote northwestern corner of Arkansas. The story, attributed to "Our Special Correspondent, Battle-Field, on Sugar Creek, Benton Co., Ark., Monday Morning, March Iо, I 862," included descriptions of the topography, conversations with locals encountered on the march out of Missouri, scathing observations on the primitive state of the inhabitants of Arkansas, names of officers and units, a clear sense of rushing about and action, anecdotes of courage and humor, and quivering outrage at the most infamous feature of the battle, the Confederates' use of a small group of American Indian troops, who scalped some of the Union dead.

The article also included very little of the sort of first-person-singular observation that was a common and accepted convention for the journalism of the time. That showed a delicacy both telling and appropriate: Browne had in fact been hundreds of miles from the battlefield at the time and had created the whole story out of rumor, reports by others who had been on the scene, the knowledge of a local man, his own imagination, and his understanding of what the officers in question would have done. He did not witness the battle himself, and while that didn't stop him from describing what went on there, except for the dateline at the top of the story (which was probably added by the editors back home) he had professional scruples enough to refrain from actually saying that he'd been there.

Richardson would later expose his colleague's subterfuge in his memoir, but he named no names and seems to have mentioned the whole affair mainly to assure his readers that this "Bohemian freak," word of which was probably circulating among the fraternity by then, was the only "manufactured" account "by any reputable journalist" to have been issued during the entire war. More than twenty years later, however, when Wilkie sat down to write his own memoir, he was much less forgiving of that "freak." In what seems to have been an example-rare for Wilkie, notwithstanding his vantage point — of a judgment sharpened by the passage of time, he assumed the role of something close to an ombudsman: fingering Browne by name, he called the article "a most remarkable production" but also "eminently offensive" and the "cruelest event of the war" for two other correspondents who had actually managed to make their way to the remote battlefield in time and had been confident they would have a magnificent scoop. Strikingly silent on the whole affair was one of those two offended correspondents, Browne's fellow Bohemian Thomas Knox himself, who said nothing at all about the episode in his own memoir. We can only guess that the most serious and professional member of the Brigade may have been honoring a kind of omertà about the flaws of his colleagues. ${ }^{30}$ 
Browne's writing on Pea Ridge quietly points up another important journalistic trend that was not specifically acknowledged by any of the four Bohemians but was certainly evident to any careful reader. Although Browne followed the convention of the time in freely expressing his sentiments and sympathies, he was also careful to couch even his fabricated report in the sturdy, serviceable, and straightforward style that newspaper readers accustomed to rough-and-ready, on-the-spot reporting would have accepted as genuine. "At about the first of last month," the piece began briskly, "Generals Curtis and Sigel left Rolla, Mo., with some seven or eight thousand men to drive Sterling Price out of Missouri, his quarters then being at Springfield, and there were many fears that with so small a force our gallant soldiers might be ensnared and defeated by the cautious and cunning Rebel chief." ${ }^{31}$

Yet after the war when Browne turned to writing his memoir, a volume he evidently intended (or at least hoped) would last for the ages, he described the very same battle in a markedly different style. Florid and romantic, comfortably familiar in tone to any consumer of Victorian high-style novels or spread-eagle speeches, his rhetoric was lavishly decorated with such glossy sentiments as these: “Man's Pandemonium is profaning the holy Night.... The stars, too, are keeping watch on the battlements of Heaven.... Speak they, or be they forever silent, there are many spirits in the air seeking peace that is not of Earth." The contrast could not be more stark between the memoir, its "writerly" tone dictated by Browne's aspirations for dignity, permanence, and importance, and the newspaper report, which derived its air of authenticity and authority from its visibly breakneck pace and aggressive freedom from airy musing and adjectival fancy. It was precisely the roughness of journalism in this era that guaranteed its readiness and that placed it in clear distinction to the ostentatious craftsmanship flaunted in the frills and furbelows of "literary" prose. To some long-lived Bohemians, however, the evolution of fashions in prose style would eventually bring an opportunity for a little double-dipping. By I 894, when Thomas Knox wrote The Lost Army, his juvenile novel about two fifteen-year-old soldier-boys at Pea Ridge, literary taste had shifted far enough from the romantic to the realistic that some of the long passages of explication he put into his young heroes' mouths included whole phrases and sentences lifted straight from his forty-year-old newspaper accounts. ${ }^{32}$

Another concern shared by all four reporters was the difficult position of the war correspondent. It was "a most thankless office," as Browne put it, insisting that the correspondent ought to have "some fixed and recognized position in the Army and Navy, or be expelled from both.... There is no middle ground." Knox, too, was troubled by the difficulties inherent in the correspondent's ambiguous standing with military authorities. In fact, that 
ambiguity could put the journalist in actual physical danger: Knox himself was nearly shot on two separate occasions by Northern troops because without a proper uniform he was taken for a spy. But the war correspondent could be confronted with less lethal uncertainties as well. Knox would be far from the last journalist to point out that a reporter's dependence on "official courtesies" was "injurious to free narration or criticism" concerning the very officials he was supposed to be covering, and he urged Congress to pass laws "establishing a position for the journalists, fixing their status in the field, surrounding them with all necessary restrictions, and authorizing them to purchase supplies and forage from the proper departments." 33

Richardson recounted with evident pride his coup in persuading the famously journalist-resistant General Sherman to give him an interview by arguing that it was not only unfair but counterproductive for the general to drive away the "reputable" journalists simply because he was angry at the "less worthy" ones who misrepresented him. And even twenty-odd years later Wilkie was still distressed that even though the war correspondent in general was uninterested in money, acting "from the love of his profession," it was nonetheless unjust that the "scant" reward received by most correspondents ranked far below that of soldiers who "incurred no greater dangers [and] who endured a less mental strain." The war correspondents "deserve a place in history," he concluded. ${ }^{34}$

Lending their words moral weight were the sufferings all four had undergone in the fulfillment of their professional duties. Wilkie was nearly killed when he caught a piece of shrapnel in the head. Knox was arrested by the prickly General Sherman after one critique too many and courtmartialed on charges of aiding the enemy, spying, and disobeying orders. He could have been shot for treason, but in the end he was acquitted on most counts. In the months before the surrender of Fort Sumter, Richardson traveled incognito throughout the South, sending back dispatches on the secessionist movement and facing the possibility of harassment, expulsion, or worse if his connection with the widely loathed Tribune became known. Later he and Browne were taken prisoner after a failed attempt to run the Confederate batteries at Vicksburg in a steam tug burdened with two hay barges. Although the rebels often released war correspondents in recognition of their special status, they refused to do so for representatives of the Tribune, and the two Bohemians spent more than nineteen months in prisoner-of-war camps (during which time Richardson's first wife died as well as the infant daughter he had never met) before making a harrowing escape through enemy lines.

Thus while each memoir included its share of ripping yarns, pillow fights, and vigorous raffishness, all four also made a conscious effort to shape their readers' understanding of how and why journalists were serious 
at heart, how they were different from other people and other writers as well. The work the Bohemians did was special: it required whole-hearted dedication as well as unique skills and character traits possessed by very few, it accomplished a crucial public service that was especially important in a time of national crisis and that deserved special accommodation by the authorities, and it merited wide recognition and respect. Clearly, not everyone could do this kind of writing. Not everyone had the ability to gain access to the events, gather and understand the facts, and cast them, in the field or on the run, in the distinctive literary style that would persuade readers they were seeing exactly what the reporters did-in short, to "photograph" the war, in Browne's telling phrase, "for the benefit of the great Public." And clearly, this kind of writing, this replication of reality produced according to understood rules, this news, held a special place within the newspaper, a place infinitely superior to that occupied by the pieces that came in, the sort of stuff that any traveler or humorist or college freshman-any amateur who wrote just for fun-could produce.

The war thus ended up pressing the group that had first been inspired by a Broadway beer cellar into presenting itself to the public as an exceptional community bound by intellectual solidarity and working to heighten its credibility and social authority in the public's eyes-arguably the first and most basic steps taken by journalists along the long road toward professionalization. A century later, television journalists would use their imperfect yet extremely visible coverage of President Kennedy's assassination as a "critical incident ... to display and negotiate the appropriate boundaries of their profession" and to "place themselves ahead of other potential retellers, narratively attending to critical events in ways that uph[e]ld their authority." So too did the Civil War correspondents emerge from their own critical incident having created a new narrative of themselves as an authoritative interpretive community. ${ }^{35}$

Nor were those the last journalistic steps to be inspired by the war. The public appetite for timely and accurate news that was a lingering legacy of that time of crisis, the decline of partisan journalism in favor of an "independent" press, the needs of a rapidly growing and industrializing postwar society, the increasing standardization of newspaper content, the rising costs of newspaper production, and the developments elsewhere in the publishing industry that better accommodated the belles lettres did soon help drive the message home to more and more papers, especially those of the metropolitan mass press, that the Bohemians were right. Though many newspapers continued to publish a range of miscellaneous and entertaining material, that sort of content was increasingly taking second place to the news, and the gathering and writing of news as such was increasingly reserved for the special kind of writer called the journalist. 
Although those journalists, averse as they were to regulation both temperamentally and Constitutionally, were not quite keeping up with the lawyers and the doctors and other such specialized workers in establishing credentialing procedures, educational requirements, or widely accepted codes of ethics and conduct, journalism throughout the Gilded Age slowly continued to assume other classic hallmarks of professionalism. Handbooks for the aspiring neophyte were published, trade journals for the questioning practitioner were launched, at least one press association was founded, and no less a personage than Robert E. Lee suggested establishing a course of study for would-be reporters at the college later known as Washington and Lee. Its main feature, however, was simply the addition of a work-study requirement in a printing office to the normal classical curriculum. ${ }^{36}$

That newspapers, and newspapers offices as well, were more and more recognized as professional places devoted to important business of a particular kind is strikingly demonstrated by the rising spate of complaints about the infamous species widely known as the "Editorial Bore" or even "the Infernal," precisely because he did not understand that distinction. Busy editors were coming to dread rather than welcome the stuff that came in along with the eager amateur who invaded their "sanctum" and "intimidate[d]" them, as one country editor complained, with "formidable rolls of manuscript ... with a request—very much like a demand-to peruse." Other bores would simply loll about the newspaper office as if it were their own parlor, reading the exchanges, hanging over the editor's shoulder, and interfering in his business conversations; they would, grumbled Mark Twain, "smoke, and sweat, and sigh, and scratch ... and never seem to comprehend that they are robbing the editors of their time, and the public of journalistic excellence in next day's paper." As the editor A. F. Hill tried to explain to the public, gently, in the entire chapter on "The Bore" he included in his I 875 guide to the "secrets" of the editorial sanctum: "You may drop in and talk to a man engaged in manual labor, and not seriously interrupt him; you cannot do so with the Editor. He works with his mind.... His tools are his brain faculties, and when you occupy them you take his tools, as it were, and scatter them around over the room." ${ }^{37}$ The newspaper was less and less a refuge for the layperson.

But it wasn't much more hospitable to the Bohemian, whose heyday hardly outlasted either the war or the publication of those three "instant books." Very soon after Appomattox, derision began descending on the breed, as well as blame for everything that was wrong with journalism. The main article of impeachment against Bohemianism sounds very close to what the crew at Pfaff's as well as their battlefield followers had once considered their most engaging quality: their disreputable air. Critics called them "unprincipled," derided them as "beery, illiterate, [and] vulgar," lamented 
their propensity for the "low and mean kind of suicide" otherwise known as drunkenness, and described the term "Bohemian" as "almost always a reproachful epithet" and the Bohemian himself as "a person who never writes English, who never ceases to carry an odor of bad liquor, and is never known to have a clean shirt." ${ }^{38}$ The beer has returned as a useful symbol.

In real life the legacy of the original Bohemians was decidedly mixed. Many members of the founding crew that had roistered at Pfaff's had in fact surprised no one (and gratified not a few) by dying young, dramatically, or both: Edmund Clarence Stedman noted in I 877 that out of the fourteen people who had shared a memorable supper at Pfaff's one night in I860, nine were dead, including Clapp, who had drunk himself to death; the playwright and short-story writer Fitz-James O'Brien, whose war-wound had led to lockjaw; the humorist Artemus Ward, carried off at thirtytwo by tuberculosis; and the scandalous actress Ada Clare, who had died horribly of rabies after a lapdog bit her through the nose. The fates of the correspondents of the Bohemian Brigade, however, were generally neither dire nor disreputable. By ı 888, when Wilkie's memoir appeared, Richardson was dead but all three of his fellow memoirists were involved in respectable literary endeavors: Knox had turned children's author, Browne was writing books and magazine essays as well as occasional newspaper contributions, and Wilkie himself had headed the Chicago Times's foreign bureau in London, marking the first time a newspaper published west of the Alleghenies had fielded its own foreign correspondent. Other Bohemian colleagues, among them Colburn, Simplot, and Lovie, had improved both their fortunes and their presentability by either marrying well, investing well, or inheriting well. ${ }^{39}$

The favorable side of the mixed legacy didn't help raise any reputations, however, and the whole Bohemian ideal generally came to be seen as a sort of youthful indiscretion long outgrown and best forgotten, more important perhaps as a symbol of declension than it had ever been as a symbol of artistic unconventionality and adventurousness. And the image of the Bohemian journalist continued to present an irresistible target to some guardians of culture, the emblem of all the childish things they themselves had put away. "There was a vealy period in our journalistic development," wrote the Tribune's editor Whitelaw Reid in I 882, "when young men, with a flavor of Byron and bad beer about them, prated of fair Bohemia, and held it noble to believe nothing.... But the age of fair Bohemia is gone, and the seedy, disreputable Bohemian lags superfluous on the stage." Even some of the survivors of the original Pfaff's group, like the Tribune's Congdon, could acknowledge that there had been "many excellent fellows and men of rare genius enrolled under the Bohemian banner," while still looking back with bemused condescension at the "harum-scarum life ... and utter 
disregard of the conventionalities and respectabilities and responsibilities.... It was jolly while it lasted, but it could not last." 40

Even some who continued to hoist the Bohemian banner found themselves forced to make the sort of compromises that would have appalled the drinkers downstairs at Pfaff's. In San Francisco, the small group of "gentlemen connected professionally with literature, art, music and the drama" who founded the Bohemian Club in I 872 soon came to realize an uncomfortable truth. "The members were nearly all impecunious," wrote one of the founders later, "and it was apparent that the possession of talent, without money, would not support the club; and at a meeting of the board of directors ... it was decided that we should invite an element to join the club which the majority of the members held in contempt, namely men who had money as well as brains, but who were not, strictly speaking, Bohemians." Yet it was those contemptible money-men, not the strictly Bohemian members like Mark Twain, Ambrose Bierce, Bret Harte, Henry George, John Muir, and Jack London, who managed to assure the "permanent success" of the club, which survives to this day as a bastion of wealth and privilege. ${ }^{41}$

A few journalists did continue to champion the genuine Bohemian life. A. F. Hill described Bohemians he had known who were brilliant poets, or accomplished linguists, or historians to rival Macaulay, but whose domestic or other disappointments had left them drifting and "disgusted ... with life itself." Junius Browne, once the happiest of Bohemians, insisted in the New York guidebook he published in I 869 that many of his journalist friends were still "Bohemians in the best sense." But he had to concede that they had come to "dislike the title because so many unworthy persons have made the name repulsive by claiming it as theirs." 42

The criticisms weren't entirely wrong. No one could deny that newspaper work occupied a strange place in the universe of mind-workers: it held a natural appeal for persons scruffy or slim of resources, and by all accounts it did involve a lot of beer, bad or otherwise. Landing a job on a paper generally seemed to require only "brain faculties," not the kind of training, connections, or nest egg that setting up as a lawyer or doctor or banker did, while the pay was so meager that journalism rarely attracted anyone respectable or responsible enough to understand the importance of a nest egg in the first place. In an increasingly bureaucratic society, the relatively independent and adventurous work of reporting held a special charm for unconventional souls who felt unsuited to both the grind of the office and the drudgery of factory or farm. The long and erratic hours didn't easily accommodate a settled home life and family.

And while the terrible conflict that was so emotionally wearing on readers and reporters alike had doubtless earned the Bohemians some 
license in matters like tidiness and pillow fights, similar indulgences seemed much less engaging after the restoration of peace. To an embattled wartime public desperate for news of life and death, the daring correspondent who went anywhere and did anything to get the story had clearly been rendering a vital service. But once the war ended, the disheveled busybody who went about poking into other people's affairs, prying into private matters, and coolly interviewing perfect strangers on no more authority than his own audacity could seem distinctly less essential to the common good. ${ }^{43}$

Yet the turnaround in the connotations of the term was devastatingly swift and alarmingly sweeping; within just a few years after the Civil War it had come to be associated with everything that was disorderly about the old Pfaffian ideal while becoming divorced from anything that was publicminded, metaphysical, authoritative, romantic, or skilled. ${ }^{44}$ Whereas the original members of the Bohemian Brigade had carefully constructed an image of themselves that had climbed out of the beer cellar and emphasized their seriousness and credibility, the postwar Bohemians had been deemed repulsive and sent en masse back downstairs.

Public distaste for the excesses of Gilded-Age journalism was widespread-and not terribly successful in effecting much improvement or change-but it is significant that so much of the most persistent and vociferous criticism of Bohemian slovenliness came from other journalistic writers. Many of those critics, moreover, had graduated from newspapers to the highbrow magazines such as the Galaxy or Harper's or Scribner's, which were generally considered, and certainly believed by the magazine writers themselves, to be custodians of culture. From those august perches these writers doubtless felt their own reputations-their own still-precarious professionalism - threatened by the disreputable colleagues who still felt too close for comfort. George William Curtis, who often used his "Editor's Easy Chair" column in Harper's to swipe at the impertinence and vulgarity of the ordinary journalist, was an alumnus of the Bohemian-tainted Tribune. And writers for the Galaxy, which started up just around the time Clapp's Saturday Press died its second death, included Stedman, Bayard Taylor, William Winter, C. D. Shanly, and other men who in their salad days had been thrilled to be published by Clapp's paper-which itself had also come to be widely seen as a youthful indiscretion. The Galaxy was particularly attentive to the work of other journalists; the critic Richard Grant White, whose regular column dealt frequently and usually disapprovingly with the press, is said to have written the first article ever to deal exclusively with journalistic standards..$^{45}$

Not only were these eminent men, these arbiters of taste, now middleaged; they were also decisively middle class, members of a group that has long had a particular and urgent interest in the idea of professionalism. 
After the Civil War, many middle-class people found membership in the newly emergent or newly strengthened professions a congenial answer to the double challenge of defining their own place in, and also imposing some kind of social order on, an urban and industrial society that seemed increasingly chaotic and unrecognizable. Members of what Burton Bledstein has called the "culture of professionalism" saw their primary goals as "earning a good living, elevating both the moral and intellectual tone of society, and emulating the status of those above [themselves] on the social ladder." It is not necessary to embrace the whole of Bledstein's controversial argument rooting the culture of professionalism in middle-class egotism and exploitativeness to understand why the group of highbrow writers was particularly anxious to challenge the standing of so feckless, intemperate, and untidy a creature as the Bohemian journalist. Someone who represented the polar opposite of bourgeois values had no business claiming the cultural authority to narrate the stories of an increasingly bourgeois nation. ${ }^{46}$

These middle-class, middle-aged cultural leaders, some of whom had once sought to proclaim their difference from ordinary mortals, now valued a different difference - the bright and important line that divided those writers and journalists who embodied social authority and upheld social values from those who challenged and debased them. ${ }^{47}$ Small wonder, then, that they distanced themselves from the embarrassments of their own youth as well as from the painfully persistent presence of their fellow mind-workers by seeking to drown all Bohemians in metaphorical buckets of beer. And the generally fruitless preoccupation of this small but vocal group with everything that was unruly about reporters nicely set the stage for the twentieth-century submersion of the reporter's self-the Bohemian's self-into the role of an objective witness who may have been doing a task quietly recognized as impossible but who was at least doing it sober and wearing a clean shirt.

\section{Notes}

I. Michael Schudson, Discovering the News: A Social History of American Newspapers (New York: Basic Books, I978), 7-9, I 52-59. See also James W. Carey, "American Journalism On, Before, and After September I I," in Journalism After September II, ed. Barbie Zelizer and Stuart Allan (London and New York: Routledge, 2002), 77-82. The sociological and historical literature on professionalism is rich and often contentious, particularly about the relationships between professional authority and such characteristics as altruism, egotism, disinterestedness, and exploitativeness; for a glimpse at some of the recent points of argument see Thomas L. Haskell, Objectivity Is Not Neutrality: Explanatory Schemes in History (Baltimore and London: The Johns Hopkins University Press, 1998), pt. 2, which includes reviews of Peter Novick's That Noble Dream: The "Objectivity Question" and the American Historical Profession (Cambridge: Cambridge University Press, I988), Burton J. Bledstein's Culture of Professionalism: The Middle Class and the Development of Higher Education in America (New York: Norton, I976), and works by Charles S. Peirce, Emile Durkheim, and R. H. Tawney. More relevant for my purposes here, however, is the relationship between 
journalists and the traits generally accepted as distinguishing a profession from a vocation or trade: autonomy, special training, a high level of skill, social authority, codes of ethics or standards of conduct, peer accountability, and a culture or sense of community. For a brief summary of some of this literature-including classic works by Talcott Parsons and Wilbert E. Moore-and its relation to journalism, see Stephen A. Banning, "The Professionalization of Journalism: A Nineteenth-Century Beginning," Journalism History 24 (Winter I998/I999): I $57-63$.

2. Schudson, Discovering the News, 66. Many authors have examined the reporting of the Civil War; standard works include J. Cutler Andrews, The North Reports the Civil War (I955; reprint, Pittsburgh: University of Pittsburgh Press, 1985) and The South Reports the Civil War (1970; reprint, Pittsburgh: University of Pittsburgh Press, I985); Louis M. Starr, Bohemian Brigade: Civil War Newsmen in Action (Madison: University of Wisconsin Press, 1987); and James M.Perry, A Bohemian Brigade: The Civil War Correspondents-Mostly Rough, Sometimes Ready (New York: Wiley, 2000). These tend, however, to emphasize either the political, military, and editorial content of the reporting or the undeniable adventurousness and romance of the reporter's job, rarely paying attention to such professional dimensions of wartime journalism as how reporters thought about themselves and the work they did, how they differentiated themselves from combatants on the one hand and other writers on the other, and how they earned the authority to narrate the war for the public. A collection of essays derived from presentations at the annual Symposium on the igth Century Press, the Civil War, and Free Expression at the University of Tennessee at Chattanooga - The Civil War and the Press, ed. David B. Sachsman, S. Kittrell Rushing, and Debra Reddin van Tuyll (New Brunswick and London: Transaction, 2000) - covers a wide range of topics, but each individual entry is closely focused. Mark Wahlgren Summers, The Press Gang: Newspapers and Politics I 865-I878 (Chapel Hill and London: University of North Carolina Press, 1994), offers a thoughtful investigation of the relationships between politics and "professional journalism fresh out of the eggshell" (2). It focuses, however, on the period after the Civil War, while the war itself is described with little elaboration as the moment when journalists felt that "their craft came into its own" ( 15 ).

3. William Winter, Old Friends: Being Literary Recollections of Other Days (New York: Moffat, Yard, I909), 60. See also A. F. Hill, Secrets of the Sanctum: An Inside View of an Editor's Life (Philadelphia: Claxton, Remsen \& Haffelfinger, I 875), I46-54; Albert Parry, Garrets and Pretenders: A History of Bohemianism in America, rev. ed. (New York: Dover, I 960), 43-45; and Frank Luther Mott, A History of American Magazines, vol. 2, I850-1 865 (Cambridge, Mass.: Belknap, I967), 38-40. Earlier usages of "Bohemian" by Scott (Quentin Durward) and Thackeray (Vanity Fair) referred to vagabond habits, not artistic ones.

4. See W. D. Howells, Literary Friends and Acquaintances: A Personal Retrospect of American Authorship, vol. 32 of A Selected Edition of W. D. Howells, ed. David F. Hiatt and Edwin H. Cady (Bloomington: Indiana University Press, I968), 63-64, on the ambition of young writers; Saturday Press, 5 Aug. I 865 , p. 8.

5. Frank Luther Mott, A History of American Magazines, vol. I, I74 I-I 850 (Cambridge, Mass.: Belknap, I957), 504-I3; Mott, American Magazines, 2: 19-25; William Charvat, The Profession of Authorship in America, I 800-1870, ed. Matthew J. Bruccoli (Columbus: Ohio State University Press, I968), 68-69; Winter, Old Friends, 79-8 I.

6. Patricia Okker, Our Sister Editors: Sarah J. Hale and the Tradition of NineteenthCentury American Women Editors (Athens and London: University of Georgia Press, 1995), 90-93, 97-I00. I want to make clear that the term "professional writer," as frequently used by such literary scholars as Okker and Charvat, must be understood somewhat differently from the idea of "professionalism" as applied to such practitioners as doctors, lawyers, teachers, and, indeed, journalists. Literary authors of course had to possess a distinguishing talent, and they sought the recognition of readers, publishers, and critics, but their great battle in the nineteenth century was to overturn the durable convention that authorship was too genteel a 
thing to have anything to do with the marketplace. While some of the institutional trappings of professionalism (e.g., credentialing, formal peer watchdogs, uniform codes of behavior and ethics) have always been problematic for journalists because of First Amendment concerns, they are generally irrelevant for literary writers. Questions of the status, social authority, and public service of artists are well beyond my scope here.

7. Okker, Sister Editors, I02, quoting Alice B. Neal, "American Female Authorship," Godey's Lady's Book (Feb. I 8 52): I 47; Greeley to H. Hubbard, I 2 April I 844, Horace Greeley Papers, Manuscripts and Archives Division, Astor, Lenox and Tilden Foundations, New York Public Library.

8. Jeffrey L. Pasley, "The Tyranny of Printers": Newspaper Politics in the Early American Republic (Charlottesville and London: University Press of Virginia, 200I), I3.

9. Hazel Dicken-Garcia, Journalistic Standards in Nineteenth-Century America (Madison: University of Wisconsin Press, I989), I8-19; Thomas C. Leonard, The Power of the Press: The Birth of American Political Reporting (New York and Oxford: Oxford University Press, I986), 70-7I; Andie Tucher, Froth and Scum: Truth, Beauty, Goodness, and the Ax Murder in America's First Mass Medium (Chapel Hill and London: University of North Carolina Press, 1994), 7-20.

Io. Gary Lamar Whitby, "The New York Penny Press and the American Romantic Movement" (Ph.D. diss., University of Iowa, I984), I65-79; Alfred McClung Lee, The Daily Newspaper in America: The Evolution of a Social Instrument (New York: Macmillan, 1937), 7 I 8 . An indeterminate number of the weeklies included in this total were the special "country editions" published by the big urban dailies for wider circulation. Exact statistics on country weeklies are difficult to come by, in part because so many of them were ephemeral, the "ignis fatuus of the press," as a census agent put it in his report on the condition of the press in I 880 . The same report noted that of the 2,605 counties that made up the United States in I 880 , an astonishing 2,079 of them published at least one newspaper. S. N. D. North, History and Present Condition of the Newspaper and Periodical Press of the United States, With a Catalogue of the Publications of the Census Year, Census Office, Department of the Interior (Washington, D.C.: Government Printing Office, I884), 93, 193.

II. David J. Russo, The Origins of Local News in the U.S. Country Press, I840s-I870s, Journalism Monographs no. 65 (Lexington, Ky.: Association for Education in Journalism, I980); Richard B. Kielbowicz, News in the Mail: The Press, Post Office, and Public Information, I700-1860s (New York: Greenwood, I989), I47-5I; Gerald J. Baldasty, The Commercialization of News in the Nineteenth Century (Madison: University of Wisconsin Press, I992), I 54.

I2. The Vincennes Western Sun of I 6 April I 836 copied the report from the Louisville Advertiser, which quoted an Arkansas Gazette extra, which cited Louisiana's Natchitoches Herald, which got it directly from the gentleman, who himself credited an "express" from San Antonio; Franc B. Wilkie, Personal Reminiscences of Thirty-Five Years of Journalism (Chicago: F. J. Schulte, I89г), го.

I3. Constance Rourke, American Humor: A Study of the National Character (193I; reprint, ed. W. T. Lhamon Jr., Tallahassee: University Presses of Florida, I986), 297-302.

I4. Smith, whose first Downing sketch appeared in I830 in his own paper, the Portland (Maine) Courier, is the only one of this group who could have been called a professional literary man at the time his work first saw print, though several of the others soon gravitated into journalism. Longstreet, then a judge, was first published in 1833 in the (Milledgeville) Southern Recorder; Derby, an army engineer, in 1850 in the Alta California; and Thomson, then a jewelry clerk, in I854 in the Detroit Advertiser. Harris, a farmer and metalworker, had published a number of other pieces in the sporting paper Spirit of the Times before the first Lovingood yarn appeared there in I $_{54}$, and Shaw, an auctioneer and real estate agent, began publishing sketches in local papers including the Poughkeepsian and the Poughkeepsie 
Daily Press around I 858 . That some of these pieces conveyed clear political messages and that nearly all relied for their humor on regional characteristics also made the local or specialized newspaper their natural home.

I 5. Perry Miller, The Raven and the Whale: The War of Words and Wits in the Era of Poe and Melville (New York: Harcourt, Brace, I956), I 5-19; Howells, Literary Friends, 65; Winter, Old Friends, 93.

I6. Winter, Old Friends, 94.

17. Junius Henri Browne, The Great Metropolis: A Mirror of New York (Hartford: American, I 869), I 53-57; Winter, Old Friends, 64-66; Charles T. Congdon, Reminiscences of a Journalist (Boston: Osgood, I 880), 336.

I 8. Shelley Fisher Fishkin, From Fact to Fiction: Journalism and Imaginative Writing in America (Baltimore and London: The Johns Hopkins University Press, I985), I3-27; David S. Reynolds, Walt Whitman's America: A Cultural Biography (New York: Knopf, 1995), I 43-44, 376-78 (Whitman's comment, to Horace Traubel, quoted at 376); Howells, Literary Friends, 66; Whitman, "The Two Vaults," in Leaves of Grass, ed. Sculley Bradley and Harold W. Blodgett, Norton Critical Edition (New York: Norton, I973, cr965), 660-6I.

19. Holmes, "Bread and the Newspaper," quoted in Alice Fahs, The Imagined Civil War: Popular Literature of the North and South, I86I-I865 (Chapel Hill and London: University of North Carolina Press, 200I), I9.

20. For contemporary references to Bohemians or the Bohemian Brigade, see, for instance, "Miscellaneous Missouri News: A Scene at Springfield," reprinted from the St. Louis Republican in the New York Times, I3 Nov. I86I, p. 2 (an account by "a gentleman" who claims that while he "do[es] not mean to disparage" the "famous Bohemian Brigade," he himself had been "a bona fide witness" to an incident involving General Frémont that the Bohemians had slept through); Galway [i.e., Brigade member Franc Wilkie], "The War in the West," New York Times, 4 Nov. I86I, p. 2, on "the 'Bohemian' Brigade, alias the Reporters' Corps"; and L. A. Hendrick, "Captivity in Rebeldom," New York Herald, 30 Jan. I864, p. I, in a reference to Richardson and Browne; for the Mobile correspondent's pen name, see Andrews, South Reports, 5 I 8.

2I. James D. Hart, The Popular Book: A History of America's Literary Taste (Berkeley and Los Angeles: University of California Press, I963), I 5 I; Browne, Four Years (Hartford: O. D. Case, I865); Knox, Camp-Fire and Cotton-Field (New York: Blelock, I865); Richardson, Secret Service (Hartford: American, I 865); Wilkie, Pen and Powder (Boston: Ticknor, I 888). The above list of Bohemians is basically Browne's, who says the original group at Frémont's headquarters was "only seven or eight in number," while others who had grown "tired or disgusted" drifted away (28). Richardson put the initial group at "more than twenty" but listed no names (I89). Two decades later, Wilkie, while noting that the Jefferson City group was "numerous," at first specifically named only the same men that Browne did (54), though in a later chapter he listed some additions to the fraternity $(84-85)$.

22. Knox, Camp-Fire, 20; Wilkie, Pen and Powder, 23-24, 7I-72.

23. George Cooper, Lost Love: A True Story of Passion, Murder, and Justice in Old New York (New York: Pantheon, I994), 9-I2, I 8-25; Wilkie, Pen and Powder, 39-44.

24. Wilkie, Pen and Powder, 52-53; Richardson, Secret Service, 340; Dictionary of American Biography, s.v. Browne, Junius Henri; obituary, New York Evening Post, 3 April I902.

25. Wilkie, Pen and Powder, 355-57; Dictionary of American Biography, s.v. Wilkie, Franc Bangs; "Franc Wilkie Dead," Chicago Daily Tribune, I3 April I 892.

26. Browne, Four Years, 45; Richardson, Secret Service, I9I; Knox, Camp-Fire, 96, 489, 73; Wilkie, Pen and Powder, 202; Browne, Four Years, 367, 238.

27. Browne, Four Years, I 5-I6.

28. Wilkie, Pen and Powder, I2, 336. 
29. Browne, Four Years, 30; Wilkie, Pen and Powder, 248-49; Knox, Camp-Fire, 46.

30. Richardson, Secret Service, 27I; Wilkie, Pen and Powder, I24-29. From the vantage of twenty-odd years, Wilkie got some of the facts wrong; he said Browne's faked account in the Tribune preceded Knox's authentic Herald one in print, but in fact the Herald's longest and most significant report had appeared on I9 March, the day before Browne's, and the excerpts of Browne's writing that Wilkie quoted as "a specimen of what can be done by a vivid imagination" came from the published memoir Four Years, not from the pages of the Tribune. Browne's Tribune article concluded with lengthy sections copied from, and attributed to, the previous day's stories from the Herald and also from the World, which included enough specific and accurate detail to suggest that it too had been written by an eyewitness notwithstanding Wilkie's assertion that the only other reporter on the scene with Knox was William Fayal from the Missouri Democrat of St. Louis. (Richardson had placed only one correspondent in the field and had implicated two New York journalists in St. Louis, both of whom he left unnamed, in the fraudulent dispatches.) Further muddying the story is the most recent history of Civil War reporting, Perry's Bohemian Brigade, which perpetuates Wilkie's error about Browne's scooping of Knox and adds a new one, noting, mystifyingly, that Richardson's memoir had identified the fabricators by name $(82-85)$.

31. New York Tribune, 20 March I862, pp. 6-7.

32. Browne, Four Years, 99-100; Knox, The Lost Army (New York: Merriam, I894), I 80-2 I 5. On the contest over the evolving plain-style in journalism and elsewhere see Kenneth Cmiel, Democratic Eloquence: The Fight Over Popular Speech in Nineteenth-Century America (Berkeley and Los Angeles: University of California Press, I99I), 246-47; Andie Tucher, "In Search of Jenkins: Taste, Style, and Credibility in Gilded-Age Journalism," Journalism History 27 (summer 200I): 52-54; and, generally, Fishkin, From Fact to Fiction.

33. Browne, Four Years, I6, 20; Knox, Camp-Fire, 490, 50-5 I.

34. Richardson, Secret Service, 248; Wilkie, Pen and Powder, 369-70.

35. Thomas L. Haskell, The Emergence of Professional Social Science: The American Social Science Association and the Nineteenth-Century Crisis of Authority (Urbana: University of Illinois Press, I977), I8-I9, citing Kuhn's argument that professionalization is foremost a measure not of quality but of community; Barbie Zelizer, Covering the Body: The Kennedy Assassination, the Media, and the Shaping of Collective Memory (Chicago and London: University of Chicago Press, I992) I9I, I98.

36. Among the earliest known handbooks are Hints to Young Editors, By an Editor (New Haven: Chatfield, I 872) and T. Campbell-Copeland, The Ladder of Journalism: How to Climb It (New York: Allan Forman, I889); see also the weekly Journalist (New York, I884-I907) and the monthly Writer (Boston, I887-). On the Missouri Press Association see Banning, "Professionalization."

37. James J. Belcher, quoting "the editor of a country afternoon journal," in "Newspaper Curiosities," Harper's New Monthly Magazine 35 (Sept. I 867): 486; Mark Twain, "Memoranda: The Editorial Office Bore,” The Galaxy Io (July I 870): I40; Hill, Secrets, 23 I.

38. W. P. A., "A Letter to a Young Journalist Whose Education Has Been Neglected," Scribner's Monthly 4 (Oct. I872): 757; William H. Rideing, "The Metropolitan Newspaper," Harper's New Monthly Magazine 56 (Dec. I 877): 48; James Parton, "Falsehood in the Daily Press," Harper's New Monthly Magazine 49 (July I 874): 276; Julius Wilcox, "Journalism as a Profession," The Galaxy 4 (Nov. I867): 798.

39. Stedman quoted in Justin Kaplan, Walt Whitman: A Life (New York: Bantam, I982), 244; Justin E. Walsh, To Print the News and Raise Hell! A Biography of Wilbur F. Storey (Chapel Hill: University of North Carolina Press, 1968), 205; Wilkie, Pen and Powder, 359-6r.

40. Whitelaw Reid, "Schools of Journalism," Scribner's Monthly 4 (June I882): 202; Congdon, Reminiscences, 337. 
4I. Edward Bosqui, Memoirs (Oakland, Calif.: Holmes, I952), I26-27; see also Joan Didion, Where I Was From (New York: Vintage, 2004, c2003), 83-84.

42. Hill, Secrets, I46-7; Browne, Great Metropolis, I 57.

43. On contemporary criticisms of the interview, see Tucher, "Jenkins," 5I-52; see also Michael Schudson, "Question Authority: A History of the News Interview," in Schudson, Power of News (Cambridge and London: Harvard University Press, I995), 72-93.

44. By I 869 "Bohemian, particularly in New-York, has indeed come to be a sort of synonym for a newspaper writer.” Browne, Great Metropolis, I 5 I.

45. On Clapp's decline, see Parry, Garrets and Pretenders, 46-48; on The Galaxy, see Mott, American Magazines, vol. 3, I865-I885 (Cambridge, Mass.: Belknap, I957), 36 I-8I; White's article, "The Morals and Manners of Journalism," Galaxy 9 (Dec. I 869): 840-47, is cited in Dicken-Garcia, Journalistic Standards, I 58.

46. Robert H. Wiebe, The Search for Order I 877-I 920 (New York: Hill and Wang, I967), I I I-I 3 ; Thomas Bender, "The Erosion of Public Culture: Cities, Discourses, and Professional Disciplines," in Bender, Intellect and Public Life: Essays on the Social History of Academic Intellectuals in the United States (Baltimore and London: The Johns Hopkins University Press, I993), 34-36; William M. Sullivan, Work and Integrity: The Crisis and Promise of Professionalism in America (New York: Harper Business, I995), 46-50; Bledstein, Culture of Professionalism, 80; Haskell, "Power to the Experts: A Review of Burton Bledstein's Culture of Professionalism," in Haskell, Objectivity, 63-77.

47. Samuel Haber, The Quest for Authority and Honor in the American Professions I750I 900 (Chicago and London: University of Chicago Press, I99I), 9I-I I 6, offers an exploration of the successful efforts by members of the more traditional professions-law, medicine, the clergy - to employ specialization to "maintain the distinction between the specially honored and authoritative profession and the ordinary occupation" (II 3 ) in the face of the midcentury trend toward egalitarianism. The attempt by the highbrow writers to assert their own gentlemanly honor by relegating the Bohemians to "occupation" status echoes suggestively here. 